\title{
Alienation and Despair in Okey Ndibe's Arrows of Rain
}

\section{Wisely C. Mkandawire}

Department of English, University of Malawi, Chancellor College, Zomba

Received: 06 Nov 2020; Received in revised form: 09 Dec 2020; Accepted: 18 Dec 2020; Available online: 31 Dec 2020

(C)2020 The Author(s). Published by Infogain Publication. This is an open access article under the CC BY license

(https://creativecommons.org/licenses/by/4.0/).

\begin{abstract}
This essay explores the themes of alienation and despair in Okey Ndibe's Arrows of Rain. The essay argues that in Arrows of Rain, Okey Ndibe depicts poor governance, political oppression, economic exploitation and suppression of human rights as the main causes of alienation and despair among the characters, and presents prostitution and mental derangement as some of the manifestations of the alienation and despair. The essay also contends that Okey Ndibe portrays alienation and despair as existential themes in the novel and he does that by presenting self-isolation, absurdity and meaninglessness of life.
\end{abstract}

Keywords-absurdity, alienation, despair, existentialism, meaninglessness.

\section{INTRODUCTION}

This essay explores the themes of alienation and despair in Okey Ndibe's Arrows of Rain. The main argument is that in this novel, Okey Ndibe depicts poor governance, political oppression, economic exploitation and suppression of human rights as the main causes of alienation and despair among the characters, and presents prostitution and mental derangement as some of the manifestations of the alienation and despair. The essay also argues that Okey Ndibe portrays alienation and despair as existential themes in the novel and he does that by presenting self-isolation, absurdity and meaninglessness of life. Abrams (1999)asserts that in the existential philosophya human being is viewed

as an isolated existent who is cast into an alien universe, to conceive the universe as possessing no inherent truth, value, or meaning, and to represent human life- in its fruitless search for purpose and meaning, as it moves from the nothingness whence it came toward the nothingness where it must endas an existence which is both anguished and absurd (p. 1).

As Sawawa \& Neimneh (2016) put it, “man's existence is absurd because his contingency finds no external justification" (p. 109).In this essay I am interested in examining this assertion in Ndibe's Arrows of Rain.

The general objective of this essay is to explore how Okey Ndibe portrays despotism as the main causes of alienation and despair in the characters depicted in Arrows of Rain. Specifically, the essay examines the frustration, anger and helplessness that characterise the individuals who engage in protest in the novel. It also investigates how the author represents the enduring effects of alienation and despair in his work.

\section{LITERATURE REVIEW}

Okey Ndibe's Arrows of Rain reveals the terrible effects of military rule in the fictitious state of Madia. The novel begins with an exhibition of the dead body of a woman sprawled on the sandy shores of B. Beach on New Year's Day. The police arrive at the scene and the only person who witnessed the death the woman is a maverick vagrant named Buruku. The man is a highly educated former journalist, although he appears to be lunatic. As the police officers interrogate him about the demise of the woman, Buruku reveals that the soldiers contributed to the death of the woman. Furthermore, he discloses that a highly decorated 
army officer has done unspeakable violence to women. The police instantly begin to hatch a cover-up. Discounting Buruku's account, the police accuse Buruku of multiple homicides on B. Beach.

Different critics have read Ndibe's Arrows of Rain from different perspectives. Most of them look at the novel as a representation of military rule in Nigeria. Akingbe(2013),for example,argues that Arrows of Rain is "a satirical and allegorical representation of Nigeria in the grip of dictatorship foisted upon it by the military in the last four decades" (p. 158). He further observes that "[t]he overt subscription to social concerns in Arrows of Rain reveals the extent of the determination of third-generation Nigerian writers to confront the social realities considered responsible for the failure of the country to live up to its widelyacknowledged potential" (p. 159). However, Akingbe does not consider the suffering of the characters in the novel as the genesis of alienation and despair.

Onwuka(2018) observes that Ndibe represents military leadership in Arrows of Rain to present to the society that "military leadership is among the worst challenges in African countries; therefore, a deeper understanding of military characters and their conduct would aid society [to] respond appropriately to it in future" (p. 40). Nguessan(2018) argues that Ndibe's Arrows of Rain depicts the early Nigerian independence period till the 1990s which is associated with "numberless flaws of political leaders who have instituted a regime of corruption, greed, starvation and sins" (p. 19). He also asserts that the novel represents Ndibe's quest to depict "a military coup that leads straight to the officialization of military delinquency" (p. 19) in Nigeria. This essay shows how the suffering of the characters under the military leadership creates senses of despair and alienation in the said characters.

\section{THEORETICAL FRAMEWORK}

This essay engages postcolonialism and existentialism theories to analyse the themes of alienation and despair in the novel. Postcolonialism is a "term with multiple meanings and political associations, cutting across and implicated within theories of imperialism, modernity, racism, ethnicity, cultural geography and postmodernism" (Darian-Smith,1996, p.291).It "deals with the effects of colonization on cultures and societies" (Ashcroft et al, 2000: 168). Postcolonial studies cover a wide range of issues in "the culture affected by the imperial process" (Ashcroft et al,
1989, p. 2) and featured in the pertinent literatures. Among such issues, which is the major focus of this essay, is the idea of violence as advanced by Franz Fanon. Fanon argues that the colonized (the native) has been fabricated by the settler to be exploitative and violent. According to Fanon (1963), "decolonization is a violent phenomenon ... [and] is quite simply the replacing of a certain species of men by another species of men" (p. 35). Fanon further asserts that colonization was associated with "exploitation of the native by the settler" through the use of "a great array of bayonets and cannons" (p. 36). As he passes through the turbulence of violent conditions, the native learns to be violent himself. This is why Fanon argues that "it is the settler who has brought the native into existence and who perpetuates his existence" (p. 35). This essay views that any form of violence in the texts understudy reflects Fanon's theorization. Some of violent acts in the works include monopolization of resources, oppression and exploitation of characters.

Existentialist fiction is "essentially literature based upon [Existentialist]philosophy" (Glicksberg, 1960, p. 192). According to Glicksberg (1960), "[a]t the heart of Existentialist philosophy is the belief that man makes himself and that in this consists his fundamental freedom. Nothing is finished and final" (p. 192). This study engages existentialism to analyze alienation and despair in the novel. The use of existentialism in the study is motivated by Jean Paul Sartre's claim that: "Existence comes before essence.....man first of all exists, encounters himself, surges up in the world - and defines himself afterwards" (Sartre, 1956 , p. 568). This essay observes that the characters in the novel come into the world before they have definite values, purposes or characters. This means that their freedom to define themselves through action determines their existence.

Alienation and despair are major themes in existentialist perspectives. Fernandez(2014) states that "the main focus of existentialism [includes] alienation and despair" (p. 42). Rothwell(2014) concurs with Jasmine Fernandez that alienation is one of the major motifs in existentialism. He argues that "in atheist perspectives of existentialism, alienation is characterized as the separation of man from society or from himself either because of himself or because of society. Man alienates himself from society and others insofar as he is drawn up within himself and ceases to relate to others or his place in society" (p. 3). Rothwell also argues that an "existential approach to life leads one to powerful contemplations of despair" (p. 3). 
Using Rothwell arguments, this essay explores the themes of alienation and despair using existentialist perspective.

\section{POOR GOVERNANCE, CORRUPTION AND PEOPLE'S SUFFERING}

Okey Ndibe portrays poor governance and corruption as the root causes of alienation and despair in Arrows of Rain. He shows that these factors instill senses of alienation and despair in the victims by subjecting them to pain and suffering. Ndibe's portrayal of corrupt leaders in the novel reflects Fanon's views on independent states. Fanon (1963) says,

Before independence, the leader generally embodies the aspirations of the people for independence, political liberty, and national dignity. But as soon as independence is declared, far from embodying in concrete form the needs of the people in what touches bread, land, and the restoration of the country to the sacred hands of the people, the leader will reveal his inner purpose: to become the general president of that company of profiteers impatient for their returns which constitutes the national bourgeoisie. (p. 166)

Fanon continues to assert that the leaders, upon realizing their faulty leadership, begin to fear the masses. Because the leaders know that the masses are aware of the fact that they are being exploited, they side with the bourgeoisie to find support from them.Fanon states that

[h] is contact with the masses is so unreal that he comes to believe that his authority is hated and that the services that he has rendered his country are being called in question. The leader judges the ingratitude of the masses harshly, and every day that passes ranges himself a little more resolutely on the side of the exploiters. He therefore knowingly becomes the aider and abettor of the young bourgeoisie which is plunging into the mire of corruption and pleasure. (p. 166)

Ndibe'spresentation ofMadia as a state that is full of corrupt and tyrannicalleaders makes the novel reflect Fanon's concept of violence and disillusionment in postcolonial states. Ndibe acts as a mouthpiece of the majority ofMadians who, at the dawn of independence, thought that their lives would be better than it was during the colonial period. As a spokesperson for the majority,Ndibe shows that "the nation inheritedfrom the English was placed in the hands of politicians whosucked its blood until it became anaemic. Overnight cabinet ministers puffed out protruding bellies they themselves called,PP, for power paunch" (p. 81). In KouakouN'guessan's words, “The elected government has turned Madia into a Sodom and Gomorrahlike city where corruption, depravity and deviant sexual activities have taken ascendance over morals. Ministers and officials are so money-centered and businesslike that dysfunction is observed everywhere" (N'guessan, 2018, p. 20). Here, Ndibe uses the metaphor of blood sucking to illustrate how greedy politicians contribute to the suffering of the people. He says, "Madia was in the stranglehold of the most vicious kleptocracy anywhere on our continent - a regime in which ministers and other public officials looted whatever was within their reach, and much that wasn't" (pp. 117-118). In this assertion, Ndibe indicates that the whole state of Madia is run by leaders who do not care about the lives of the masses; leaders who plunder public funds without concern about the suffering of the people. This means that the leaders are alienated from the general masses.

Ndibeilluminates the issue of corruption through the dialogue between Buruku (Ogugua) and Pa Matthew Ileke Ata, the father of Rueben Ata, the Minister responsible for Social Issues before the coup. Ogugua tells $\mathrm{Pa}$ Ata what he sees as corrupt practices in the country. He does not hide a word considering the fact that the man he is speaking to is the father of one of those stealing government resources. He states:

You hear all these stories about ministers using public funds to buy cars for their mistresses. Or acquiring European castles for themselves. How can you not think it? You go to any village and you're shocked by the squalid life there. The dust roads.Hospitals that have neither drugs nor doctors. The polluted stream water the people drink. The lack of electricity. Then, as you're trying to come to grips with a reality that seems to belong in the Middle Ages, up comes a Rolls Royce carrying some ministers to remind you that you're not in the sixteenth century after all but in twentieth. Then you're faced with the pathetic irony of the villagers lining up to hail the nabob in the Royce - the very man who's plundered the country. (p. 120)

The politicians are here presented as people who use government resources on trivial issues leaving important things unattended to. Most importantly, the community needs things like good roads, probably tarmac ones, so that 
their movement is not deterred by mud during the rainy season. People need enough drugs and health personnel in public health facilities. People also need safe drinking water. Instead of attending to these problems, the leaders use government resources to buy less important things like cars for their women.Ogugua finds it hard to see these problems as existing in modern times when they should have belonged to the Middle Ages or in the sixteenth century not in the twentieth. It appears that the masses have accepted their condition of abject poverty and deprivation. This acceptance is indicated by the fact that, although they are suffering at the hands of these leaders, they still praise them as demi-gods.

In this regard, Ndibe concurs with Lawal et al(2012) who assert that "[t]he problem of Africa'sDevelopment is a crisis of governance" (p. 188). AsSandbrook(1985) puts it, one of Africa's economic crises is "political decay, evident in widespread corruption, bureaucratic immobilism, political violence and instability" (p. 2).Images of sufferingare evident in this context when Ndibe presents poor masses using "dust roads", having "hospitals without drugs or doctors", drinking "polluted stream water" and "having noelectricity" (p. 120).

However, for Pa Ata, corruption is not an inherent part of Madia and the colonized people. It is a condition that has been inherited from the colonial masters. He also considers the colonialists as thieves. He argues that "[i]n the old days, before the whiteman came and stood our world on its head, no man who was given something to hold in trust for the community would dare steal from it to serve himself" (p. 121). In this statement, Pa Ata tries to exonerate the precolonial period by presenting it as a time without corrupt leaders, and therefore, his views suggest that African leaders inherited everything colonial.He depicts the colonial administrators as thieves by stating that one of the things white administrators did in the colonies was to steal.

They were officially licensed to pilfer our treasures in the name of their monarch. They taught our present leaders all the tactics of stealing. The only difference is that the whiteman stole for his country, our people steal for their pocket(p. 121).

In other words, Pa Ata suggests that the white administrators stole state resources out of patriotism in order to enrich their country. On the other hand, the postcolonial leaders of Madia steal the resources out of greed. They do not even think about their own people. This makes the masses suffer and become alienated from the society.
Through this situation, Ndibe shows that the Madian leaders who took over power from the colonialists abuse their authority and separate themselves from the masses.

Ndibe also illustrates that poor governance and corruption result in coup de tat in Madia. The coup is the aftermath of the political unrest in Madia. The people of Madiawant Dr. Titus Bato, the Honourable Minister of National Planning and Economic Development to be removed from the ministerial position, but the Prime Minister of Madia, Askia Amin, refuses. Dr. Bato angers people with his callous sentiments on the report issued by The Stockholm-based Hunger Institute. The report states that "food production in the country [has] declined by thirty percent; the birth rate is increasing exponentially, and life expectancy [has] shrunk from fifty-seven, five years ago, to fifty-two" (p.187). This report also projects that within a decade two thirds of the children born in Madia will live in excruciating poverty, and that people will literally drop dead in the streets from acute malnutrition. In response, Dr. Bato tells the members of the House of Representatives and Senate that if the report is true then it is good news. He says,

[i]t's hard to understand. The Hunger Institute claims that the food crisis will lead to a dramatic rise in death rate in Madia. It also claims that there has been an explosion in the birth rate in recent years. The total picture is therefore that the death rate will cancel out the birth rate, thus preserving the standard of living. Even children who understand simple arithmetic can follow that logic. (p. 189)

This results in mass demonstrations throughout the country. Ndibe states that "university students and labour unions called for nation-wide strikes and daily demonstrations until the minister was fired" (p. 190). The government decides to suppress the situation by ordering the police to shoot the demonstrators. Ndibestatesthat "[t]he police launched an overwhelming arsenal of tear gas which sent the students scattering, eyes streaming. Then the police released a rattle of machine-gun fire" (p. 190). The confrontation results in military coup. The coup appears to have come to relieve the people from the corrupt regime.In his speech on the national radio Major James Rada justifies the decision to oust the civilian government. He explains,

Fellow citizens, we have all been witnesses to the escalating acts of irresponsibility and corruption exhibited by the political classes. The ordinary 
citizen has lost all confidence in the institutions of governance; the state and national treasuries have been bankrupted by politicians for their own profit; and the moral fabric of this nation has been torn apart. (p. 191)

In other words, the military government wants to free the citizens of Madia from the bondage of the corrupt politicians who oppress and exploit the people.However, it should be pointed out that Ndibe's portrayal of the political pandemonium in Madia seems to illustrate ChidiOkonkwo's argument about the destabilizing influence of the West on formerly colonized states. According to Okonkwo (2004), western countries treat

$[\ldots]$ their ex-colonies not as independent states but as mere counters in their strategic maneuvers. The West continued to interfere secretly or intervene openly in these states' affairs to overthrow governments that they considered ideologically unacceptable, murder leaders whose policies were considered hostile to Western interests, foment civil wars to destabilize some countries, or install puppet regimes. (p. 1198)

In a clear reflection of Okonkowo's argument, Ndibe relates the coup that has made Isa Palat Bello ascend to power to the colonial mission to destabilize postcolonial Africa. He presents Bello as a leader who has been groomed in the west. First, Bello joins his country's army through the British Army, and later he is sent to the west for six months' training. From there, he is chosen to be the leader by the soldiers who have oustedAskia Amin from power.

The military government is not better than the former. In this dictatorship, people are detained without trial, and worse still, they are summarily executed. Buruku comments on the detentions without trial when he talks to Dr. Mandi, a psychiatrist who has been sent by the government to cross examine his mental status. Buruku says to Dr. Mandi: "If my fate is already sealed, then why are you here? Why is there a trial at all? The system you serve could have thrown me in jail without trial. It happens every day" (p. 75).

Ndibe refers to the summary executions when he shows the ruthlessness of the military leadership.This happens through the narration of oppressive incidences that occur upon Pallat Bello's ascension to power. He says that "Six months after Bello's ascension to power, newspapers reported that ten army officers, including Major-General
James Rada, had been found guilty of treason and executed" (p. 212). It is ironically notable that Major-General James Rada is one of the army officers who led the coup, and he is the one who announced that the government had been taken over by the military. However, as Bello is in power, he sees Rada as a threat and, presumably, he executes him together with the other officers in order to silence possible opposition to his dictatorship.

Buruku reports that the regime's atrocities reach him through the BBC's broadcasts, and he reads about them in the foreign newspapers that are discarded by diplomats. Most of the stories he reads have the following headlines:

MADIAN WRITER HANGED- He was a critic of the dictatorship

MADIAN MINISTER'S DEATH

SUSPICIOUS- Dictator said to be having an affair withdeceased's wife

$120 \quad$ STUDENT PROTESTERS
REPORTED KILLED
DESPOT CANES VICE-CHANCELLOR
IN PUBLIC

DIPLOMATS SAY AFRICAN DICTATOR BEHIND DISAPPEARANCE OF OPPONENTS- Victims may have been fed to lions. (p. 213)

The headlines clearly reveal that the dictator commits the various atrocities to silence individuals or groups that express opposition to his rule through direct criticism or protests. The extensive nature of the oppression is illustrated by the different classes of its victims who range from a writer to students and a vice-chancellor. It is noteworthy that the newspapers that explicitly report the atrocities committed by the military ruler are foreign ones. The local newspapers would not dare comment on the evil activities of the government. However, Buruku reveals that a local newspaper which works clandestinely in the state explicitly depicts what Bello does to the public. Buruku observes:

The underground opposition press painted a picture that was even more grim: countless men picked up and tortured for saying a bad word about Bello in an unguarded moment in some bar; women, too, detained and tortured; children orphaned by assassins. Bello's rapaciousness had catapulted him to the front ranks of the world's wealthiest potentates, behind the 
Emir of Brunei, but ahead of Zaire's quick-fingered man-god. (p. 213)

In addition to showing the suffering of the people who are subjected to detention and other forms of torture in the society, Ndibe also shows that there is no freedom of expression as the local press has to work secretly to publish stories that depict the evils of the government. Consequently, the people are denied full access to information on what is happening in their country. In the novel, Ndibe employs "[t]he mythological contextualisation of rain [to] underscore the image of the military" (Akingbe(2013, p.167). As observed it is justifiable for the military to take over the elected government.This is because the elected government has destroyed the orderliness of democracy. In other words, the military government has come like rain to give life.

The military as paralleled against the rain can be seen within the context of two conflicting concepts of human development which are discernible throughout the novel: the one imagines the military as a rescue platform for liberating a depraved country from the grip of its civilian political elite; the other, typified by the gratuitous brutality and mass killing, imagines the military as representing a degeneration from human civilisation to the abyss of human degradation. (Akingbe, 2013, p.167)

Clearly Ndibe shows that the military, just like the metaphorical rain, "has two faces." "It can give life but its arrows can also cause death"(p. 196).

The soldiers in Madia capitalize on the oppressive leadership to abuse the people. They sexually abuse prostitutes in the country. They ambush the prostitutes and load them into their truck and drive to the beach where they rape and abandon the victims. Buruku witnesses the soldiers raping the prostitutes. One of such victims in the novel is TayTay, who tells Buruku that during the time when the soldiers captured them, "One of the girls kept shouting that she was not a prostitute. The commander of the troops slapped her until she collapsed. Then he stood over her. Smiling, he said, "If you are not a prostitute that means you're fresh meat. That's the kind I like. I will make you a prostitute"” (p. 216). The soldiers also subject prostitutes to gang rape.TayTay tells Buruku that "After the first two, I stopped counting. It could have been one soldier tearing my thighs apart. Or all the soldiers of the world" (p. 217).In KouakouN'guessan's words, "The rape of the girls who are supposed to be prostitutes equates with that of the country by indigenous rulers who have betrayed people, dashed their hopes, and raped their manhood and dignity before subjugating everybody like in colonial times" (N'guessan, 2018, p.21). It follows that Ndibe presents rape incidents to symbolize the suffering of the people in Madia.

Ndibe shows that the soldiers wield so much power that they are virtually above the law. The police and judiciary fail to enforce justice when the soldiers commit crimes. When Buruku is caught, he explicitly tells the police that soldiers are behind the death of a prostitute found lying dead on the B Beach. Instead of the police investigating the case in order to uncover who these soldiers are, they conclude that Buruku is a prime suspect of murder.

\section{ESTRANGED SOULS AND HOPELESSNESS}

In Arrows of Rain, Ndibe presents prostitution, loss of identity, and mental delirium as manifestations of the alienation and hopelessness of the characters victimized by the political oppression in their society. According to Chukwumezie (2014),

In social psychology, an alienation results in the withdrawal of the individual from the society and such isolation expresses itself in the act of neurosis. Worst still is the interiority of alienation in social theory, in the sense of the individual being out of touch with himself, a fragmenting of oneself. Be it the social, economic, or psychological dimension, alienation manifests arguably in the characters' actions, state of being or state of mind, as well as physical uprooting, if not dislocation from one's original home. (p. 10)

In the novel,Ndibe portrays different characters who withdraw themselves from their habitual association in response to different situations.

\subsection{Isolation and Prostitution}

In his presentation of prostitution as a manifestation of the affected characters' alienation and despair,Ndibe also shows that the society regards prostitution as the profession of the outcast. Consequently, the society considers prostitutes as self-estranged individuals. This attitude is indicated in two ways. First, a prostitute is presented as an ogbanje. Second,Iyese chooses to become a prostitute and changes her name to Emelia.

Ndibe uses an old man to show how the society perceives prostitutes. The old man who is present at the site 
of a dead woman at B. Beach says that the prostitutes are ogbanje. This old man responds to a question from Lanky, a man working as a lifeguard at B. Beach: "Why would a dying woman smile? Perhaps she saw the home of the dead and liked it more than this wretched life" (pp. 7-8). The old man says,

'She's an ogbanje. Only an ogbanje would smile at death. I'm certain of that.' [...]

Ogbanje. They can die and return to life over and over again. To them, death is a game, that's why they can laugh at it. Death only means a brief visit to the land of spirits. Then they return to this life.

'How does a dead person return to life?' asked the American.

'It's a secret known only to ogbanje,' asserted the old man.

'And most prostitutes are ogbanje. That's why they live the way they do. Their bodies are like borrowed things, so they use them anyhow, without regret.' (p. 8)

In other words, an ogbanje is a person who repeatedly dies and comes back to life. Therefore, such a person is not as normal as other people because he or she is both a physical and spiritual being. The old man's identification of prostitutes as ogbanje seems to be justified by the promiscuous sexual behavior of the prostitutes. In this regard, the old man sees abnormality in prostitution, because the society has its own conception of the normal ways in which a human body is supposed to be used. The prostitutes' reckless usage of their bodies shows their deviation from the society's norms, and signifies their self-estrangement. In this case,Ndibeuses the myth of Ogbanjeto illustrate alienation of the characters.

In his description of the dying woman, Buruku seems to show that the prostitute sees death as a means of escape from her condition of suffering in the world. Buruku observes: "The dying woman turned her head ever so slightly towards me. Her eyes were red, as if daubed in blood, but the expression on her face was turning into something radiant and peaceful. A smile" (p. 222).Through this depiction of a smiling corpse,Ndibe seems to present the meaninglessness of life. It appears that the dead person has seen the world of the dead to be better than the world of the living in which she has been. Ndibe reflects the existentialist's assertion that "There is no ultimate meaning or purpose inherent in humanlife; in this sense, life is 'absurd', man is 'forlorn', 'abandoned' in the world to look after himself completely” (Odesanmi, 2008, p. 85).

Ndibe further shows that prostitutes are not regarded as humans in Madia through the way the soldiers dehumanize them. When the prostitutes, including TayTay, have been taken by the soldiers, they are told that they are bush meat. They are gang raped. TayTay tells Buruku that the soldiers "called [them] bush meat and boasted how they [the soldiers] would show [the prostitutes] 'army fire" (p. 217). The objectification of these prostitutes as bush meat implies that they are not human beings. The prostitutes are physically isolated and alienated from what the society regards to be normal human beings.N'guessan (2018) argues that "When the militaries ousted the corrupt and bankrupt government and Bello becomes head of state, they see rapes as a way to satisfy their frustrated masculinity". Since the soldiers target any girl found on the roadside when their trucks are passing, Nguessan continues to argue that "One can thus opine that girls are just scapegoated for the numberless flaws of society" (p. 20).

In addition to being alienated from their humanity by this objectification, some of the women turn to prostitution out of despair. This happens when they do not see any way out of their situations. For instance, Iyese chooses to engage herself in prostitution after being disappointed by her husband. She initially gets married to Dr. Maximus Jaja, the man who at first espouses Marxism and he is a good man. But as a punishment for his ideological position, the government sends him to Utonki a "poor settlement that [is] cut off from the rest of the world" (p. 134).

Iyese marries Dr. Jaja against her family's rejection of the marriage.The family does not accept Dr. Jaja because of both his impoverished state and his old age. The family members see that the man is both too poorand too old for Iyese. The grandmother explicitly tells Iyese that "[t]here's another thing, child of my womb. Who cannot see that this man is too old for you? When a man is as old as he and unmarried, something is not right. His people need to take him to a medicine man" (p. 145). Against this advice, Iyese tries as much as possible to defend her position for choosing this man. She tries to convince the grandmother that their marriage will be a good one. She says, "Yes, Great Mother. Maximus and I will have a good marriage. I will never run away like an ogbanje. Maximus will change"(p. 146). This 
Affirmation later makes it difficult for her to go back to the village after she divorces Dr. Jaja.

In the early period of their marriage Iyese and Dr. Jaja live happily together. The situation changes when Dr. Jajawants to have a child and engages in an extramarital affair with Nnenne to bear him a child. Dr. Jaja confesses his being engaged in an extramarital affair to his wife after ten months when Nnenne is three months pregnant (p. 153). Although Dr. Jaja tells Iyese in his confession that he still loves her, the situation leads Iyese to despair. She remembers that she married this man against the wishes of her family members.

Dr. Jaja's confession that he is involved in a love affair with Nnenne, whom he has impregnated, traumatizes Iyese so intensely that she is rendered speechless. Throughout the period during which Dr. Jaja tells her the story of Nnenne, Iyese remains quiet. The author only reveals her mental reactions to the news as Dr. Jaja speaks:

'You have to talk to me. Silence is not the answer. It's unfair ... I mean, unnecessary. Yes, it's unnecessary. Try to express your feelings. Please.

May the eyes with which you saw this woman be gouged out.May the legs that carried you to her collapse under your weight.

hate me.'

'Yes, even look me in the face and tell me you

Why! You must roast in a slower fire! (p. 154)

Here, Iyese's inability to speak is a result of her confused mind. What has happened to Iyeseillustrates Shoshana Felman's argument that any form of pain that a person experiences mutes the language. In other words, the person in pain becomes speechless:

To seekreality is both to set out to explore the injury inflicted by it - to turn back on, and to try to penetrate, the state of being stricken., wounded by realityand to attempt, at the same time, to reemerge from the paralysis of this state, to engage reality as an advent, a movement, and as a vital, critical necessity of moving on. It is beyond the shock of being stricken, but nonetheless within the wound and from within the woundedness that the event, incomprehensible though it may be, becomes accessible. The wound gives access to the darkness that the language had to go through and traverse in the very process of its frightful falling-mute. (Felman, 1995, p.34)

After DrJaja stops speaking, Iyese falls into a state of total mental confusion and loses consciousness.

He fell silent, rose from his seat and began to pace the room. It was only at this moment of mutual speechlessness that the pain began to seep into her, to enter her through all the feeling spots in her body. As it drilled towards the centre of her being, she felt the room begin to spin in circles, slowly at first and quickly gathering motion.

The air became dense, blue, his face, before her, appeared to expand and dissolve. The room swam, her head rang with echoes. An anguished groan, involuntary, broke her silence as she slid into unconsciousness. (p. 154)

It is this heartbreaking situation that makes Iyese to go for a divorce. However, she finds it hard to return to her home village because, as noted already, her family members did not accept her marriage to Dr. Jaja. Therefore Iyese decides to go to Langa.

[A]fter the sad end of her marriage, she had made an impulsive decision to leave Bini immediately too many of her dreams were tied to the city, as were the cruelest of the sufferings - and head, not in the direction of her village, where her family would receive her with resentment or pity, but towards Langa, a city she had never visited before but to which she was drawn because of what she had heard - that it was a vast, strange human bazaar where shame had no odour because people lived anonymously, where some of the most beautiful people walking the streets were ghosts and some of the saddest were corpses waltzing to their graves. (p. 157)

Here, Iyese chooses to isolate and alienate herself from her family members. The city which Iyese chooses to go to is home to many alienated souls. She chooses to go there because she feels that in Langa there shall be no element of feeling ashamed with whatever she will be doing as a prostitute. This indicates that her life has become meaningless, and that the normlessness of the society accentuates the alienation of the people, especially the prostitutes. In this regard, Iyese's choice to be a prostitute confirms Ruth Dean and Melissa Thomson's assertion that most people "[become] prostitutes out of desperation, 
because they [see] no other way of surviving" (Dean \& Thomson, 1998, p.19).

The alienation of the prostitutes is further indicated by the fact that they conceal their real identities in the society. They do this in two ways. First, they are comfortable doing their work at night, and secondly they prefer using false names as they are doing their business. Iyese tells Buruku that night is the most appropriate time for them to do their business:

Because the night gives us cover from prying eyes. Besides, our customers seem more comfortable at night. We are more shadowy then. They don't have to see us clearly. They can think of us as creatures of pleasures, creatures of the night, belonging to a different category from other women. They can't handle seeing us any other way. They are scared to see that we're the same as their wives, their daughters, their sisters. If they saw that their manhood would shrivel up. That's why they prefer to meet us at night, in dark rooms. (p. 131)

In other words, the prostitutes willfully estrange themselves from the society by doing their work at night to protect both their real identities and marketability. If they operated during the day time, the men who buy their services would fail to differentiate between their normal women and the prostitutes. As a result, these prostitutes would never find men to sleep with.

Iyese adds that prostitutes use false names in order to hide their identities because they do not wish to be recognised. They also hide their real names in order to avenge themselves on the men who treat them as only objects of their pleasure not normal human beings:

Have you never wondered why prostitutes use false names?

... It's a sort of revenge. If men pretend we're mere shadows, then there's no use giving them our real names. It's our way of saying that the whole situation is false- that they, too, are unreal. It also signals to them that they are unworthy of trust. We don't let them know our real names, and when we have sex with them we don't let them touch our real bodies. A prostitute carries two spirits within her. With one she goes out into the night. With the other she lives a normal life. A false name keeps our two spirits apart. If we didn't keep them separate, we might go mad. (p. 132)
The prostitutes are not what they appear to be at night because the profession does not constitute their essential humanity. The false names construct the professional identity, whereas their essential humanity is defined by their concealed real names. This dual identity in itself signifies the alienation of the prostitutes from the community in which they live and from the men who sleep with them. Therefore, the men have no access to the women's essential humanity which, together with their real names connects them to their familial relations. Iyese sheds more light:

... Take me, for instance. My real name is Iyese. The name connects me to the spot where I was born, to my mother's womb, my father's blood, my brothers and sisters, my childhood memories. It's the name with which I get angry or feel happy. With it I smile my true smiles, laugh my deep laughter, and shed my real tears. It's the name with which I sigh at life. When I stand before the mirror, it's Iyese I see. When I dream it's the name with which my mother's voice calls across the valley warning me to run from the demons. It's the name that flows into my ears as water flows upon its bed of washed stones and white sand. Iyese is the name with which I see the world in the day. It's the name that reminds me of what contains shame or honor. It's a name with which I make love, which I do. (p. 132)

Here, Iyese mentions all aspects of her essential humanity which constitute her identity and are defined by her real name. These aspects include her biological connection to her parents and siblings, as well as how she perceives the world and herself in relation to the totality of her physical, social, psychological, and emotional experiences. Therefore, according to Iyese, a person's real name is very important to her identity. The individual's roots are traced through the real name, as it is associated with all things that comprise one's identity as a normal person. As Hogan (1994) argues, "The name has a psychological effect on the behavior and character of the bearer. Thus, the name becomes a particularly important node of social and personal identity" (p. 107). In the novel, Okey Ndibe's representation of characters with fake names can be said to be aimed at depicting the characters' alienation in the society.

\subsection{Absurdity and Meaninglessness of Life}

Abrams (1999) asserts that in the existential philosophya human being is viewed "as an isolated existent who is cast into an alien universe, to conceive the universe as 
possessing no inherent truth, value, ormeaning, and to represent human life - in its fruitless search for purpose and meaning, as it moves from the nothingness whence it came toward the nothingness where it must end - as an existence which is both anguished and absurd" (p. 1). AsSawwa\&Neimneh(2016)put it, "man's existence isabsurd because his contingency finds no external justification" (p. 109).

Buruku lives a life that is absurd and has no meaning. He does not want to tell the police his real name because for him the police and he are from different spheres. Lanky, the lifeguard, has signaled to the police that the last person to witness the drowning of the dead prostitute is Buruku. But when Buruku is asked by the police officers about his identity, he tells them that he has no name:

'What is your name?' The detective asked.

'I have no name, said Buruku.

'What do you call yourself?' Persisted another officer.

'Nothing. I don't have that need.'

'What do your friends call you?' Asked another detective.

'Oh, friends.' He raised his head as if in thought. 'Different things.Depends.'

'Say one. One name,' the detective goaded.

'That's between my friends and me,' said Buruku.

'Names shouldn't be a secret,' said the chief detective.

'Mine are not secret to my friends.'

'We're officers of the state,' the chief detective announced in a grave tone. 'That's why we ask in the name of the state.'

'Good. The state is not one of my friends.' (p. 12)

In this dialogue, Buruku refuses to tell the police his name because he does not identify himself with them as his friends. And he is alarmed when he is asked what his friends call him. When the police officers tell him that they represent the state, Buruku says that the state is not his friend.
Ndibe's presentation of Buruku as a person without identity continues when Buruku is arrested. First, the press release after the arrest of Buruku shows that the arrested man has no identity: "The suspect who refused to give his name and whose age has not been determined is of no fixed address" (p. 15). In the hands of the police, Buruku remains a stranger, a person with no traceable roots. This forces the police to identify him with the name Mr. X. As John Lati, the head of detectives, continues to interrogate Buruku, he finds that Buruku maintains his anonymity, and realizes that his effort to probe the man to mention his name is futile. When Lati angrily continues to ask Buruku to reveal his name, the man says, "Secret, Exile, Bubble, Void. I have many names" (p. 58). With this answer, Lati commands his junior to write down Buruku's name as Mr. X. Although his subordinate reminds him that $\mathrm{Mr}$. $\mathrm{X}$ is only for unidentified male corpses, Lati commands the junior officer to do what he has been told. In this regard, Buruku is depicted as a man who is "out of harmony", and he is "an exile in a meaningless universe" (Siuli, 2017, p. 338).

The names that Buruku wants to be identified with show that he is both in despair and alienated. The names "Secret, Exile and Void" show that he is not part of the world in which he is living and that he is identifying himself with those who are regarded as non-entities in the society. And by being given the name Mr. X, Buruku is associated with unidentified corpses. All this implies that Buruku is not a normal human being.

Burukucomes to his senses soon after he is arrested for allegedly committing murder. He says,

Until I found myself in an unmarked police car, handcuffed, I had never really examined the disheveled life I led as an exile. Indeed, as my years on B. Beach stretched out, it had come to seem as if the most important detour in my life had taken place in a vast vacuum, outside the regimen of time and space. (p. 59)

This realization indicates that Buruku has lived an alienated life: a life without meaning. What has happened to Buruku corresponds to what Sidney Joe Jackson posits about an alienated person. According to Jackson (1983), an alienated person "has a sense of meaninglessness or emptiness to his life" (p. 156). Jackson further argues that "[i]n suffering from anomia the individual is deprived of the emotional basis for the conduct of his life. In being so deprived he suffers meaninglessness. He experiences his 
own life as a void, bereft of purpose and meaning" (p. 150). This situation may lead to an individual's loss of direction whereby he or she cannot physically ascertain what has happened to him or her.

In a police car, Buruku realizes that he stinks. He recalls, "The stink of my body filled the car, repellent even to my nostrils. I remembered a favourite saying of my grandmother's: 'The odour that makes a man want to run away from himself carries death"” (p. 59). This reawakening to his physical being shows that Buruku had all along lost his powers of sense perception. He could hardly feel even what happened to his own body. This perceptual impairment is what Jackson (1983) means when he says that the alienated person has a "sense of not being 'himself' but of presenting an artificial façade" (p. 151). Jackson refers to this condition as 'sham' which means "a concealment of how we really feel and pretense of feeling something different" (p. 151). By failing to recognize how his body behaves for a long time, Buruku appears to have been self-alienated. In other words, Buruku is inauthentic.The term inauthenticity refers to "a condition of not being aware of one's own desires" (Sweeney, 2014, p. 6). "Alienation prevents a person from expressing his authentic self, [such as] his freedom" (Hansen, 1976, p. 122). According to Tan (2007), "If a human being denies his full humanity, that is, his being-foritself, then his denial is called inauthenticity." Tan adds that "authenticity means being able to be honest to one's own essence. Also, to be able to live authentically, man ought to be aware of his freedom and his task to create himself with its inevitable anxiety." (p. 8). It therefore follows that Buruku's loss of perceptual powers and sense of his own humanity implies his loss of authenticity.

Ndibe also presents Buruku's experience of alienation, despair and fear when he is arrested and forced into a lonely cell. This experience is evident as Buruku reflects on his situation:

Alone in a cell my heart shriveled within me. The cell reeked of a variety of smells, mementoes left by all the previous occupants. The four walls seemed to draw imperceptibly closer, threatening in time to meet in an embrace and crush me. Death entered and stayed in my thought. (p. 67)

Buruku sees death in the cell. The room is beyond habitable condition.

The alienating effect of Buruku's enclosure is also manifested through the warders' treatment of him. It appears that having put him in a cell, the warders regard Buruku as a stranger. They dare not come close to him. They even fear to have their eyes and his meet. Buruku says, "The other warders know to keep their distance, allowing me some space. They announce their presence discreetly, as if their eyes dread the prospect of meeting mine. Even when they bring me the bland-tasting beans that are the staple diet here, they shy away from my gaze" (p. 68). The behavior of the guards indicates that Buruku is an alien in their world and accordingly they avoid coming close to him. In addition to this reduction of Buruku to an alien, his confinement in the cell accentuates his sense of estrangement and despair by literally excluding him from the general society. In the cell, Buruku loses hope that he will ever be free again.

Buruku's experience behind the cell walls illustrates Carlo Bordoni's view of walls as devices used by people in power to alienate others:

If, historically, life could be guaranteed only within closed places, protected and organized by a higher authority who had the power to control the territory, it followed then that the wall has changed meaning: the free place became a place of constraint, [...] especially for those who had to be kept separate from the others because they were considered dangerous for the others, as a result of a conviction or a disgrace. (Bordoni, 2017, pp.44-45)

CarloBordoni describes this type of separation as "ostracism" which is an "alienation enforced by the polis" (p. 45). In this regard, the authorities use "the wall, the compound to lock up, remove from the sight and forget" (Bordoni, 2017, p. 45). Bordoniconcludes that "[w]hether it is a case of being removed from the confined place where the community lives or reclusion in a private place, with no visibility, they both represent the same way of 'separation' from others, which then means removing from the consciousness, burying" (p. 45).

To make sure that the arrested people are totally kept away from the society, the authorities have built the prison where Buruku is locked up very far from the general public. $\mathrm{He}$ is locked up at Bande maximum security prison. Buruku states that

Bande maximum security prison was the brainchild of Askia Amin, our country's first prime minister. He had seen a model for it during an official visit to 
Latin America. Upon his return, he signed an order for a replica to be built in a reclaimed swamp, in a location as remote from the bustle of life as possible. He had no wish for the intended inmates - his political enemies- to be reached by the familiar sounds of the human world. Such sounds could only be a distraction to men and women secluded in the prison to contemplate the truths of life. (pp. 43-44)

The remote location of the prison and the intention of the prime minister to shut the inmates out of the normal human world clearly reveal the primary purpose of the prison system. This purpose is to alienate from the society people who are considered dangerous to the politicians.

Ndibe also presentsBuruku's mental disturbance as an indicator of his alienation and despair. Buruku's mental confusion becomes clear when Iyese (Emelia) is killed by Palat Bello, the man who exchanges blows with Buruku over Iyese. Palat Bello finds Buruku in Emelia's residence. When a quarrel erupts between Emelia and Bello, Ogugua [Buruku] intervenes and knocksBello down. The fight creates animosity between the two. The following night Bello revisits Iyese's room, and he callously stabs her vagina and then rapes her.

In the morning, Buruku finds Iyese covered in blood. Iyese rejects Buruku's proposal that she should be taken to the hospital. She argues, "I'm ready to die today. This kind of life has no meaning" (p. 167).This situation affects Buruku's life negatively. He laments:

The sight and smell of Iyese's blood stayed with me as I rode to work. I felt as if I were choking. I wound down the car's window and shut my eyes, trying to conjure up other images. Gore infected every picture I saw in my mind's eye. In the end, unable to escape the memory of what I had seen, I let my mind return to what it dreaded, to the sight of the pillows drenched with Iyese's blood, her grimaces and groans, the despairing anguish in her voice when she told me what Isa and his thugs had done to her. (p. 169)

Buruku is traumatized by the sight of Iyese's blood. The brutal stabbing and rape of Iyese by Palat Bello has created fear in his mind probably because he sees his fate in Iyese's suffering. He makes the intensity of his fear evident when he asserts that his "anger at Isa Palat Bello and his minions was becoming mixed with fear for [him]self, lest [he], too, fall victim to their butchery. Slowly, the fear encircled the anger, nibbling away at it. In the end the outrage was in the belly of the fear, the anger was eclipsed" (p. 167). Consequently, he decides to avoid visiting public places. He stops visiting Iyese regardless of the many letters that Iyese writes him. In effect, the fear for his life aggravates Buruku's alienation and despair.

As he thinks about what has happened to Iyese, Buruku thinks of how to avengeher suffering, but he realizes that he lacks the means to fight the thugs. He says, "Something told me that Iyese would count on me to avenge her. But how? With what tools could I stand up to her violators? A pen? Against men who had daggers? Moral indignation?Against men with guns?" (p. 170) Buruku's failure to fight for Iyese haunts him for the rest of his life. Buruku's real name, Ogugua is a short form of "Oguguamakwa" which means "the wiper of tears, a consoler, a vindicator and comforter" (Akingbe, 2013, p. 166). It follows that his failure to avenge Iyese is against his nature. As his mental anguish intensifies, Buruku recalls:

Night visions began to poach my peace. Unable to sleep or to rest, I would lie still in a dark made unfamiliar by demons, scared of what might bare its face if I turned on the light. Breathing hard, waiting for the figures in the dark to disappear, I would be tormented by the feeling that I had again entered Iyese's head. Against my will I eavesdropped on her thoughts and mapped her body's aches and pains. Was this my punishment for befriending and deserting her? (p. 173)

Buruku's hallucinations about Iyese further indicate his alienation and despair as he fails to erase the image of Iyese'ssuffering from his mind.

Violet comes to Buruku's office to tell him that Isa Palat Bello has killed Iyese. She tells him that Bello needed to own the baby but Iyese refused. Instead, Iyese told Bello that the baby's father was Buruku. Consequently, Bello chose to kill both, but the baby has survived. Buruku realizes that his life is in danger and restricts his movements in fear of meeting Bello. He states:

Yet Isa Palat Bello continued to haunt my mind. He was present in every soldier's face, eyes peering out at me, lustful and ugly. I began to dread the approach of night, for his face would loom up out of the dark. Whenever I heard footsteps behind me I whirled around. I stopped going out at night. When friends complained about this I lied: I had been 
diagnosed with a rare disease that brought on sudden fainting spells; my doctor had ordered me to rest in bed. (p. 185)

Buruku's avoidance of places he used to visit at night because he fears for his life signifies that he is both alienated from his usual community and in despair about his future. Buruku is relieved whenBuruku hears that "Bello [is] among ten officers on their way to Pakistan for six-month advanced artillery course" (p. 185). But his fear resurfaces when he hears that Bello is declared the ruler of Madia after a coup.

A day after the coup Major James Rada returned on the Radio Madia and announced that Major Isa Palat Bello, just selected as the new head of the state and commander-in-chief of the Madian armed forces, was about to address the nation. Hearing Bello's name, I had the fleeting urge to laugh. Certainly, I thought, someone at the Radio Madia had decided to make a ghastly joke at my expense. (p. 201)

This announcement is a hard blow to Buruku. The rise of Bello to power marks the resumption of Buruku's suffering. Buruku knows fairly well that after the elimination of Iyese, he is the next target. As Bello speaks, Buruku visualizes what happened to Iyese. He starts avoiding his office when the receptionist tells him that two men have been to his office to see him. Furthermore, he is told that these men have left no names. At night Buruku starts experiencing hallucinations again.

At midnight I got to bed to sleep. The instant I shut my eyes the image of Major Bello stood over me, his gun aimed at the ridge of my nose. Lying on my back, I peered straight into the gun's muzzle, dark and small. I struggled hard to erase this image from my mind. (p. 203)

Through these hallucinations, Ndibe shows that the fear that has been instilled in Buruku by Bello's rise to power causes him to suffer mental conflict. He is hardly able to sleep because his mind is filled with phantoms. Consequently, Buruku decides to run away from his own apartment as he feels that he is not safe to live there. First, he calls Ola Jones, his university friend, and tells him: "My life's in danger. I must come over to your house" p. (203).Buruku's decision to run away from his own home signifies his despair and shows that he is a person who has lost hope of survival in his home. Although Buruku sees his friend's home as a place of safety,stay in Ola's house does not bring him peace of mind as he continues to experience mental conflict. He says, "I stayed awake each night, holed up in the dingy room where Ola dumped his dirty clothes. I read books and drank brandy and had wide-eyed dreams in which terror appeared in all guises. In my solitude I began to hold conversations with myself" (p. 207).

At Ola's house, Buruku is visited by his friends who were his mates at the university. These friends reveal something that completely changes Buruku's life. Eze, one of the friends, poignantly says to him, "Imagine what would happen to [Ola] if - God forbid- General Bello were really out to get you and Ola was caught sheltering you" (p. 209). This statement makes Buruku realize that his friends are not happy with his stay in Ola's house, and he decides to vacate the house secretly. He states:

Very early the next morning I gathered my clothes into a bundle wrapped in a blanket, then slipped out of the house before Ola woke up. The streets wore a dull, indistinct face, the houses obscured by the morning mist. I had no destination in mind when I began my journey. But as the mist lifted and the sun broke through, the clouds in my mind cleared away and I saw where I was going. I had a vision of a sand, sea, sunshine, and endless sky. My path was leading me into exile on the outer edges of life, in the haven of B. Beach. (p. 209)

These words indicate that Buruku's departure from Ola's house makes him to be mentally confused. As he leaves the house his mind seems to be erasing all the troubles that he has had before. But this apparent erasure does not necessarily mean that he is freed from mental conflict. The reality is that his mind is confused further to the extent that he no longer sees his problems as problems.

In the final analysis, Ndibe shows that the effects of alienation and despair are enduring. In this regard, he portrays Buruku as having reached a point of no return, whereby he cannot come backto his former normal life. Buruku realizes this situation as he yearns for the lost identity:

Sometimes I ached for my former life and considered returning - moving back into my apartment, presenting myself at the office in the hope that no one had been appointed to my desk. It was a ridiculous dream: the door back to that other world had been snapped shut never to be prized open again. (p. 211) 
Buruku is clear that going back to his normal lifeis impossible. He calls his wish to go back to his normal life "a ridiculous dream" because he knows that there is no way out of the situation he is in.

\section{CONCLUSION}

In Arrows of Rain, Okey Ndibe demonstrates that alienation and despair are inevitable to people who live in extreme fear. It has been observed in this essay that Ndibe's character, Ogugua (Buruku) is hopeless and estranged because he lives in a world of terror. Ogugua has been shown to have lost his mind due to his fear of the ruthless leadership of the regime. He has chosen to exile himself at B. Beach and later he has been arrested to exclude him from the general public. It has also been demonstrated in this essay that Ndibe depicts family conflicts as one of the causes of alienation and despair. Family conflicts force Iyese into prostitution, and Ndibe represents prostitution as a profession that manifests the alienation and despair of the characters who engage in it. The prostitutes signify this alienation and despair through adoption of false names. For instance, Iyese gives herself the name Emelia to hide her real identity.

\section{REFERENCES}

[1] Abrams, H. M.(1999). Glossary of Literary Terms. Heinle \& Heinle,

[2] Akingbe, N.(2013).Rallying against Dehumanization: Repudiating Military Brutality in Okey Ndibe's Arrows of Rain. Nordic Journal of African Studies, 22(3), 158-176.

[3] Anazodo, R.O., Igbokwe-Ibeto, C. J.\&Nkah B.C. (2015).Leadership, Corruption and Governance in Nigeria: Issues and Categorical Imperatives. An International Multidisciplinary Journal, Ethiopia.9(2), 41-58.

[4] Ashcroft, B., Griffiths, G. \& Tiffin, H. (2000).Post-Colonial Studies: The Key Concepts, Routledge. Ashcroft, B., Griffiths, G. \& Tiffin, H. (1989). The Empire Writes Back: Theory and Practice in Post-Colonial Literatures, Routledge.

[5] Bordoni, C. (2017). State of Fearin a Liquid World. Routledge.

[6] Carter, D. (2006). Literary Theory. Pocket Essentials.

[7] Chukwumezie, E. (2014). Alienation, Identity Crisis and Racial Memory: The Realities of Blacks in Diaspora in Andrea Levy's Fruit of the Lemon. International Journal of Linguistics and Literature (IJLL). 3(1), 9-18.
[8] Darian-Smith, E. (1996). Postcolonialism: A Brief Introduction. Social \& Legal Studies.5(3) (pp. 291- 299). Sage Publication

[9] Dean, R. \&Thomson,M. (1998)Teen Prostitution. Lucent Books, Inc.

[10] Fanon, F. (1963).The Wretched of the Earth. Grove Press

[11] Felman,S. (1995).Education and Crisis, or the Vicissitudes of Teaching in Trauma. Explorations in Memory. Hopkins University Press.

[12] Fernandez, J.(2014). Goat Days: A Study in Existentialism. IOSR Journal of Humanities and Social Science (IOSR-JHSS) 19(1), 42- 45

[13] Glicksberg, C. I. (1960). .Literature and Religion: A Study in Conflict. Southern Methodist University Press

[14] Hansen, E. (1976).Freedom and Revolution in the Thought of Franz Fanon. Ufahamu: A Journal of African Studies. 7(1), 114- 142. https://escholarship.org/uc/item/96q7k8h6

[15] Hogan, P. C. (1994).Mimeticism, Reactionary Nativism, and the Possibility of Postcolonial Identity in Derek Walcott's Dream on Monkey Mountain. Research in African Literatures, 25(2), 103-119.Caribbean Literature Indiana University Press. http://www.jstor.org/stable/4618266

[16] Jackson, S. J. (1983).The alienation of the individual from society: A social-psychological theory and cross-cultural comparison [Retrospective Theses and Dissertations, Iowa State University. 8484]. Iowa State University,

[17] Lawal, T., Imokhuede,K. \&Johnson,I. (2012), Governance Crisis and the Crisis of Leadership in Nigeria. International Journal of Academic Research in Business and Social Sciences. 2(7), 185-191.

[18] Ndibe, O. (2000). Arrows of Rain. Heinemann Educational Publishers.

[19] Nguessan, K. (2018). Military Delinquency in Okey Ndibe's Arrows of Rain. International Journal of Multidisciplinary Research and Publications (IJMRAP).1(7), 19-25.

[20] Odesanmi, A. C. (2008).Jean Paul Sartre and the Concept of Determinism. Global Journal of Humanities. 7 (1\&2), 85-89.

[21] Okonkwo, C. (2004).Casualties of Freedom. Literary Theory: An Anthology (pp. 1197 - 1209). Blackwell Publishing Ltd.

[22] Onwuka, E. (2018). Reading the 'Military Virus' in Postcolonial African Novels: Chinua Achebe's Anthills of the Savannah and Okey Ndibe'sArrows of Rain in Context. GEGE: Ogun Studies in English. 9(1 \& 2), 2012- 2015.

[23] Rothwell, A. T.(2014). Salvation from Despair and Estrangement: An Analysis of Religious Existentialism as Found in Søren Kierkegaard and Paul Tillich [Master's thesis, Texas A\&M University]. Texas A \& M University,

[24] Sandbrook, R. (1985). The Politics of Africa's Economic Stagnation. Cambridge University Press. 
[25] Sarfraz, H. (1997). Alienation: A Theoretical Overview. Pakistan Journal of Psychological Research. 12 (1-2), 45-60.

[26] Sartre, J. P. (1956). Being and Nothingness. Trans. H.E. Barnes. Philosophical Library.

[27] Sawawa, N. M. \& Neimneh,S. S. (2016). Existence vs. Essence: An Existentialist Reading of Clive Barker's "Human Remains." International Journal of Humanities and Social Science.6 (6),107- 113.

[28] Siuli, S. (2017).Existentialism and stark note of Alienation in the Modern Literature- A detail analysis in terms of Post Modern Literature." Research Journal of English Language and Literature (RJELAL) A Peer Reviewed (Refereed) International Journal. 5(1), 336- 341

[29] Sweeney, E. C. (2014). Anselm on Human Finitude: A Dialogue with Existentialism. The Saint Anselm Journal. $10(1), 1-10$.

[30] Tan, T. (2007). Existentialism And Samuel Beckett's Two Plays: Endgame and Happy Days [Master of Arts in English Literature Thesis, Middle East Technical University]. 